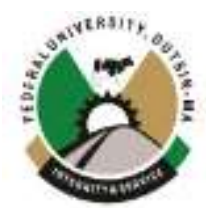

\title{
EVALUATION OF THE QUALITY AND PROXIMATE COMPOSITION OF BEEF SOLD AT THE ABATTOIR OF KANO STATE, NIGERIA
}

\author{
${ }^{1 *}$ Datti Y., ${ }^{1}$ Umar A. and ${ }^{2}$ Hafsat N. \\ ${ }^{1}$ Department of Chemistry, Yusuf Maitama Sule University, Kano State, Nigeria. \\ ${ }^{2}$ Shehu Idris College of Health Science and Technology Makarfi, Kaduna State, Nigeria \\ *Corresponding Authors' email: yaudatti@gmail.com
}

\begin{abstract}
This research was aimed at evaluating the $\mathrm{pH}$ of beef, as well as its cook loss value and water holding capacity, as well as its proximate composition of the beef from the Kano State abattoir. The proximate composition of the beef was also analyzed using standard procedures described by the Association of the Official Analytical Chemists (AOAC). The beef samples were aseptically obtained from the Kano state abattoir during the month of September when the animals were well fed and healthy, with five cows randomly selected and used for the analysis. The results indicate the $\mathrm{pH}$ for the beef to be 5.9, while the cook loss and water-holding capacity were found to be $32.71 \%$ and $24.33 \%$ respectively. The proximate contents were also reported as follows; protein content (21.50\%); fat content $(6.75 \%)$; ash content $(0.92 \%)$ and moisture content $(68.19 \%)$. The results in indicate that all the parameters analyzed for the beef obtained from the Kano abattoir are comparable with the results reported by various researchers, and are all within the standard acceptable limits. Consequently, this impart positive economic implications to the both seller and the consumer, as well as enhancing the meats taste and palatability. The present study concluded that the meat from the Kano State abattoir can be safely consumed by the consumers.
\end{abstract}

Keywords: Beef, Cook loss, Water-holding capacity, Abattoir, Proximate composition.

\section{INTRODUCTION}

Meat is the animal flesh that is eaten by man as food (Lawrie and Ledward 2006). The use of meat as food has been in existence since prehistoric times (Leroy and Praet 2015; Klaudia and Wojciech 2018). Meat belongs to one of the six major classes of food that provides the body with high quality essential proteins, minerals, vitamins and nutrients (Oh et al., 2016), as well as minerals and vitamins in order for the body to remain strong and healthy (Tsegay et al., 2015). Meat can be processed or manufactured products prepared from animal tissues, as well as all other animal tissues that are suitable for human consumption (Soniran and Okunbanjo 2002; Ameha 2006). Meat obtained from cattle is usually referred to as beef (Piatti-Farnell 2013).

The most important and most valuable components of meat are water, proteins, fats and minerals (FAO 2004; Ahmed et al., 2010; Tsegay et al., 2015), with the minerals and other chemical compositions of cooked meat drastically different from that of raw meat (Sainsbury et al., 2009; Tsegay et al., 2015). The effect of cooking on meat has also been studied, and it is reported that cooking increases the palatability, consumer preference, tenderness and the nutritive value of the meat (Pietrasik et al., 1995; Tornberg 2005; Tsegay et al., 2015). However, during cooking certain components of the meat are likely to be lost, with the lower the loss, the better the palatability of the meat (Ameha 2006; Tsegay et al., 2015) Such components likely to be lost include the water content.

The quality of beef is usually evaluated by the consumers on the basis of its tenderness, palatability, colour, juiciness, flavour content, neatness, etc. (Beriain et al., 2001), but scientifically, and probably the best way to evaluate and determine the quality of beef is to measure its water holding capacity, cooking loss, its $\mathrm{pH}$, and its chemical composition (Abd El-Aal and Suliman 2007; Fakolade and Omojola 2008; Gustavson et al., 2011; Tsegay et al., 2015).

Deficiency of protein in most African countries is mainly the cause on malnutrition in both adult and children (Omoregie, 2001; Amaefule et al., 2006; Adejinmi et al., 2007) and this can be reduced to minimum with the availability of good quality meat (Adeniyi et al., 2011), since more than half of the World's cattles, buffaloes and sheeps are found in African countries (FAOSTAT 2000; Adeniyi et al., 2011).

An important quality of beef is its $\mathrm{pH}$, which may vary between different cattle as a result of age of the animal, nutritional deficiencies, physical exercise and sex (Simela, 2004; Zhang et al., 2010; Gebrehiwot et al., 2018). When beef is cooked there is always reduction in its weight, and this is referred to as cooking loss. Cooking loss has both negative and positive effects to the consumer and the meat industry, because the meat products tend to loss a large amount of proteins and several essential minerals, and this causes drop in its nutritional quality, and subsequently lowers its purchasing value (Pearson and Gillett 1988). Another important factor that affects the quality of beef is the drip loss, or simply called the waterholding capacity. The quality of the beef and its yield are drastically reduced by low water-holding capacity. Low water- 
holding capacity also decreases the beef's juiciness and tenderness, and this reduces its demand by the consumers. However, beef's proximate composition is by far the most important quality (Pethick et al., 2011).

The main objective of this study is to determine and document on the quality and proximate composition of the beef meat sold at the abattoir of Kano state, Nigeria.

\section{MATERIALS AND METHODS \\ Sampling}

Sampling was done in the month of September when the animals were well fed and healthy. The sampling was spread across the month, with the first sampling done in the first ten days of the month (Sample A), while the second one conducted in the second ten days of the month (Sample B), and the third and the last sampling was done in the last ten days of the month (Sample C). And during each sampling five cows were randomly selected and used.

Fresh skeletal muscles from the cows were obtained from the Kano State abattoir in the early hours of morning when mass slaughters were done. Five slices (of reasonable and near same sizes) of the beef were made and then immediately put into a clean and dry jar for transportation to the laboratory for further analysis. Each procedure was repeated in triplicates and their averages reported.

\section{Determination of the $\mathrm{pH}$ Value of the Beef}

To obtain the $\mathrm{pH}$ of the beef, the method reported by Tsegay et al., (2015) was adopted. Here $0.5 \mathrm{~g}$ of the sample was ground in a blender and then diluted with $5 \mathrm{ml}$ of distilled water, and the $\mathrm{pH}$ value was measured using the $\mathrm{pH}$ meter. This procedure was done in triplicate and during each measurement, the $\mathrm{pH}$ meter was recalibrated and the blender and all the apparatus used were washed with distilled water.

\section{Determination of Cooking Loss of the Beef}

The cooking loss of the beef was analyzed using the procedure described by Bouton et al., (1971) with slight modification as reported by Tsegay et al., (2015). Three fresh slices of the beef of $0.5 \mathrm{~g}$ weight were separately placed into three different test tubes, and were then placed in a boiling water bath for 5 minutes and then removed and cooled. The cook loss of the beef was obtained by taking the difference of initial and final weight.

That is:

$$
\text { Cook Loss }(\%)=\frac{W 1-W 2}{(W 1)} \times 100 \%
$$

where:

$\mathrm{W} 1=$ Initial weight of the sample

$\mathrm{W} 2=$ Final weight of the sample.

\section{Determination of Water Holding Capacity of the Beef}

The water holding capacity of the beef was determined using the method suggested by Kauffman et al., (1986) and Trout (1998), as modified and reported by Tsegay et al., (2015). Here
0.5 gram of the sample was placed between two filter papers, and this in turn was placed between two glass sheets weighing $4.64 \mathrm{~g}$, and over all these a $50 \mathrm{~g}$ weight was placed. This gave a total compression weight of $54.64 \mathrm{~g}$ on the beef. The set-up was allowed to stand for $24 \mathrm{hrs}$. The water from the meat was found to be compressed and squeezed out and then absorbed into the filter paper. The filter paper was then dried, and the area of the filter paper for the shape of the meat and that of the absorbed water were measured using a plastic ruler. The water holding capacity was obtained by taking the difference between areas of absorbed water borderline on the filter paper (moisture) and the area covered by the meat.

That is

$$
\text { Water Holding Capacity }(\%)=\frac{A 1-A 2}{(A 1)} \times 100 \%
$$

where;

A1 $=$ Area covered by the absorbed water

$\mathrm{A} 2=$ Area covered by the beef.

\section{Proximate Composition of the Beef}

Determination of total protein, fat ash and moisture were performed according to the methods described by the AOAC (1990).

\section{Determination of Meat Protein}

The protein content of the beef was determined according to the method suggested by AOAC (1990) using the Kjeldhal method. Here 0.5 grams of the beef sample was put into a digestion tube and $5 \mathrm{ml}$ of concentrated sulphuric acid $\left(\mathrm{H}_{2} \mathrm{SO}_{4}\right)$ was added. Analyses were all carried out in triplicates and two blank samples without the beef sample were also taken. The digestion tube with its content was then placed in boiling water for 40 minutes and then the catalysts, $\mathrm{CuSO}_{4}$ and $\mathrm{K}_{2} \mathrm{SO}_{4}$, were added in the ratio of 7:1, and $10 \mathrm{ml}$ of concentrated, $\mathrm{H}_{2} \mathrm{SO}_{4}$ was added, and then transferred to the digestion block. The sample was then digested at $300^{\circ} \mathrm{C}$ for $3 \mathrm{hrs}$, until when the sample turned colorless. The sample was removed from the digestion block and then allowed to cool overnight. The aliquot was then diluted with distilled water to make up the volume to $250 \mathrm{ml}$. The sample was then made alkaline by adding $10 \mathrm{ml}$ of $35 \%$ $\mathrm{NaOH}$, and then distilled, with the distillate collected in a flask containing $4 \%$ boric acid $\left(\mathrm{H}_{3} \mathrm{BO}_{3}\right)$, with bromocresol green taken as the indicator. The distillate was then collected for 5 minutes considering that all the ammonia was collected in the boric acid solution, and then titrated with $0.1 \mathrm{~N} \mathrm{H}_{2} \mathrm{SO}_{4}$. The nitrogen obtained in the sample was then multiplied with 6.38 to determine the percentage protein of the beef.

$$
\% \text { Nitrogen }=\frac{(\text { Volume of sample }- \text { Volume of blank }) \times N \text { of acid } \times 1.4007}{\text { Weight of sample in grams }}
$$

$$
\% \text { Protein }=\% \text { Nitrogen } X 6.38
$$

\section{Determination of Beef Fat}

The beef fat was estimated using soxhlet extraction method as suggested by AOAC (1990). Three samples of 0.5 grams each of the dried beef samples were placed on a separate filter paper 
and each properly tied with a string and then placed into a fat free thimble, and petroleum ether was used for the distillation. The samples were severally refluxed in the soxhlet apparatus to ensure complete removal of the fat. The sample was then taken out of the soxhlet apparatus and then it was transferred to a rotary evaporator to remove the solvent (petroleum ether). The sample was then reweighed after overnight cooling and the difference between the original and final weight was calculated using the formula below.

$$
\text { Fat }(\%)=\frac{W 1-W 2}{W 1} \times 100 \%
$$

where;

$\mathrm{W} 1=$ Initial weight of the sample (before extraction)

W2 $=$ Final weight of the sample (after extraction).

\section{Determination of Ash Content of the Beef}

The ash content of the beef was determined using the dry ashing technique as reported by Tsegay et al., (2015). Here three slices $(0.5 \mathrm{~g}$ each $)$ of the fresh beef were taken into different silica crucibles, and were then transferred into a muffle furnace. The furnace was then operated at a temperature of $600^{\circ} \mathrm{C}$ and maintained for 6 hours. The samples (in the crucibles) were then allowed to cool overnight. The cooled crucibles (with their contents) were then transferred to a desiccator and then weighed. Each sample was weighed and reweighed three times and then the average weight was taken. Finally, the ash content was calculated using the formula below:

$$
\% \text { Ash Content }=\frac{\text { Weight of the ash }}{\text { Weight of the sample }} \times 100 \%
$$

\section{Determination of the Moisture Content of the Beef}

To determine the moisture content of the meat the technique reported by Tsegay et al., (2015) was adopted and modified. Here the $0.5 \mathrm{~g}$ of the fresh beef was placed on a flat bottom aluminum dish, which was then heated at $105^{\circ} \mathrm{C}$ overnight in hot oven. The sample was placed in a desiccator and then allowed to cool. The dried and cooled sample was then reweighed. The weight was taken three times and average weight calculated. The moisture content was measured as a difference between the initial and final weight of the sample.

$$
\text { Moisture Content }(\%)=\frac{W 1-W 2}{W 1} \times 100 \%
$$

where;

$\mathrm{W} 1$ = Initial weight of the sample

W2 $=$ Final weight of the sample.

\section{RESULTS AND DISCUSSION}

Results

The results for the $\mathrm{pH}$ value of the beef obtained from the Kano abattoir, along with its cooking loss and water holding capacity, as well as its protein, fat, ash and moisture contents are all

\begin{tabular}{|c|c|c|c|c|c|c|}
\hline S/NO & PARAMETER & SAMPLE A & SAMPLE B & SAMPLE C & $\begin{array}{l}\text { MEAN } \\
\text { VALUE }\end{array}$ & $\begin{array}{l}\text { STANDARD } \\
\text { VALUE (FAO) }\end{array}$ \\
\hline 1 & $\mathrm{pH}$ Value & 5.9 & 5.6 & 6.2 & 5.9 & $5.6-7.1$ \\
\hline 2 & Cook Loss $(\%)$ & 32.63 & 33.02 & 32.48 & 32.71 & $25-35$ \\
\hline 3 & $\begin{array}{l}\text { Water Holding Capacity } \\
(\%)\end{array}$ & 24.29 & 24.93 & 23.76 & 24.33 & $35-40$ \\
\hline 4 & Protein content $(\%)$ & 20.87 & 22.07 & 21.54 & 21.50 & $22-30$ \\
\hline 5 & Fat $(\%)$ & 7.28 & 6.09 & 6.88 & 6.75 & $1.8-2.5$ \\
\hline 6 & Ash Content (\%) & 0.86 & 0.96 & 0.93 & 0.92 & $0.9-1.2$ \\
\hline 7 & Moisture Content (\%) & 67.89 & 68.61 & 68.08 & 68.19 & $60-75$ \\
\hline
\end{tabular}
presented in Table 1 below.

Table 1: Results of the Quality Parameters of Beef Obtained from Kano Abattoir

\section{DISCUSSION}

The $\mathrm{pH}$ value (5.9) obtained for the beef obtained was found to be similar to that (5.6) reported by Tsegay et al., (2015), but was lower than the values reported by Fakolade and Omojola (2008) and Maiti and Ahlawat (2011). Low pH values may be attributed to the high lactic acid content in the muscles, and this can be due to several factors ranging from the distance travelled by the animal before slaughter, to the pre-slaughter handling, inadequate resting facilities between the travel and slaughter, (Yacob 2002; Ameha 2006; Elias et al., 2007), as well as the animals sex, with lactating mothers having low $\mathrm{pH}$ values because of constant conversion of glycogen to lactic acid (FAO 2004). Cooking loss of beef is the loss during cooking, and it measures the decrease in edible meat weight for human consumption (Gustavson et al., 2011). The mean value for the cook loss of the beef sample reported in this research work (32.71) was found to be similar to that reported by Tsegay et al., (2015) who reported 33.8\% cook loss for beef from Hawassa city in Southern Ethiopia. The values are however higher than those reported by Jama et al., (2008) for Nguni, Bonsmara and Angus cattle breeds. The difference may be due to the breed of the animal, age and sex (Ameha 2007).

The water holding capacity of the beef sample reported in this study $(24.33 \%)$ was found to be lower than those reported by Abd El-Aal and Suliman (2007), but higher than that reported by Adam et al., (2010). The values are however comparable to that reported by Maiti and Ahlawat (2011) and Tsegay et al., (2015). Low water-holding capacity makes the appearance of the meat unattractive, and consequently less attractive or appealing to the consumer, and this leads to low sells and turnover (Jama et al., 2008). Consequently, low water-holding 
capacity will have economic implications to the both seller and the consumer, as well as in the eating quality (Qiaofe and DaWen 2008).

The proximate composition of the beef obtained from the Kano abattoir was found to be similar to several reports by some researchers. The mean protein content for beef reported in this study $(21.50 \%)$ was comparable to those observed and reported by Fernanda et al., (2003), Williams (2007), Fakolade and Omojola (2008) and Nikmaram et al., (2011). Arse et al., (2013) also reported a mean value of $23.2 \%$ for the beef of Arsi cattle in Adama town, Oromia, Ethiopia, and their result supports the observed result reported by the present research work. On another hand, the mean fat content $(6.75 \%)$ reported for the beef from Kano abattoir was found to be similar to those reported by other researchers (Fernanda et al., (2003), Williams (2007), Fakolade and Omojola (2008) and Nikmaram et al., (2011) who reported similar results. With Arse et al., (2013) also reporting a mean value of $6.86 \%$ fat for the beef of Arsi cattle in Adama town, Oromia, Ethiopia, and their result supports the observed result reported by the present research work. The result for the ash content in beef in this research work $(0.92 \%)$ was found to be similar to the results reported by Fernanda et al., (2003), Fakolade and Omojola (2008) and Nikmaram et al., (2011), with result (0.99\%) reported by Arse et al., (2013) for the beef of Arsi cattle in Adama town, Oromia, Ethiopia, supporting the result reported by the present research work.

The result of the moisture content in beef obtained from Kano abattoir was found to be $68.19 \%$ and this agrees with similar result of $69.82 \%$ reported by Arse et al., (2013) for the beef of Arsi cattle in Adama town, Oromia, Ethiopia, and their result supports the observed result reported by the present research work. The result is also similar to that reported by Fernanda et al., (2003), Williams (2007), Fakolade and Omojola (2008) and Nikmaram et al., (2011). Note that, the moisture content of the meat is the amount of water held within the structures of its muscles, while the water holding capacity of the meat is the ability of the meat to retain that water (or moisture) when external force is exerted on it (Gebrehiwot et al., 2018). External forces like excessive heat, long distance walk, and poor storage of meat, thirst and starvation, as well as meat processing techniques may have negative effect on the water holding capacity of the meat (Gebrehiwot et al., 2018).

\section{CONCLUSION}

In this research work, the beef sold at the Kano State abattoir was collected and its quality and proximate compositions were analyzed using various techniques. The results obtained indicate that the $\mathrm{pH}$ value, cook loss, water-holding capacity, the protein, fat, ash and moisture contents of the beef obtained from the Kano abattoir are comparable with the results reported by various researchers. All the values were found to be within the standard acceptable ranges, and hence the meat from the Kano State abattoir can be safely consumed by consumers.

\section{REFERENCES}

Abd El-Aal HA. and Suliman AIA. (2007): Carcass Traits and Meat Quality of Lamb Fed on Ration Containing Different Levels of Leucaena Hay (Leucaena leucocephala): Scientific
Paper Presented at International Congress on Animal Husbandry "New Perspectives and Challenges of Sustainable Livestock Farming", Belgrade. Pp. 3-5.

Adam AAG., Atta M. and Ismail SHA. (2010): Quality and Sensory Evaluation of Meat from Nilotic Male Kids Fed on Two Different Diets. Journal of Animal and Veterinary Advances. 9(15):2010-2012.

Adejinmi OO., Hamzat RA. and Fapohunda JB. (2008): Performance and Nutrient Digestibility of Rabbits Fed with Fermented and Unfermented Cocoa Pod Husk. Nigerian Journal for Animinal Production 34(1):63-68.

Adeniyi OR., Ademosun AA. and Alabi OM. (2011): Proximate Composition and Economic Values of Four Common Sources of Animal Protein in South-Western Nigeria, Zootecnia Tropical, 29(2):231-234.

Ahmed AG., Adam MA and Samir HAI. (2010): Quality and Sensory Evaluation of Meat from Nilotic Male Kids Fed on Two Different Diets. Journal of Animal and Veterinary Advances 9(15):2008-2012.

Amaefule KU., Ironkwe MO. and Ojewola GS. (2006): Performance of Growers Pullets Fed Raw or Processed Pigeon Pea Seed Meal Diets. International Journal of Poultry Science 5(1):60-64.

Ameha S. (2006): Meat Quality of Selected Ethiopian Goat Genotypes under Varying Nutritional Conditions. Ph.D. Thesis. University of Pretoria, South Africa. Pp. 26.

AOAC (1990): Official Methods of Analysis of the Association Chemists, W. Howrtez (ed.) 15th edn. Varginia, USA. Pp. 684.

Arse G., Mohammed Y. and Ameha S. (2013): Evaluation of Proximate Composition of Beef of Arsi Cattle in Adama Town, Oromia, Ethiopia International Journal of Agriculture Innovations and Research 1(6):183-187.

Beriain M.J., Bas P., Purroy A. and Treacher T. (2001): Effect of Animal and Nutritional Factors and Nutrition on Lamb Meat Quality. ETSIA, Universidad Pública de Navarra, crta. El Sadar, s/n, 31005 Pamplona, Spain. Laboratoire de Nutrition et Alimentation, INA-INRA, 16, rue Claude, 75231 Paris, France. Pp 75-81.

Bouton P E., Harris PV. and Shorthose WR. (1971): Effect of Ultimate $\mathrm{pH}$ Upon the Water-Holding Capacity and Tenderness of Mutton. Journal of Food Science 36:435-439.

Elias Mu., Berhanu G., Hoekstra D. and Jabbar MA. (2007): Analysis of the Ethio-Sudan Cross-Border Cattle Trade: The Case of Amhara Regional State. IPMS (Improving Productivity and Market Success) of Ethiopian Farmers Project Working Paper 4. ILRI (International Livestock Research Institute), Nairobi, Kenya. Pp. 41. 
Fakolade PO. and Omojola AB. (2008): Proximate Composition, $\mathrm{pH}$ Value and Microbiological Evaluation of 'Kundi' (Dried Meat) Product from Beef and Camel Meat. Conference on International Research on Food Security, Natural Resource Management and Rural Development. Meat Science Laboratory, Animal Science Department, University of Ibadan. Nigeria. October 7-9.

FAO (2004): Food and Agricultural Organization of the United Nations. Retrieved July 15, 2004; from FAOSTAT on-line database,

http://faostat.fao.org/faostat/default.jsp?language=EN\&version $=$ ext\&hasbulk $=0$

FAOSTAT (2000): Food and Agricultural Organization of United Nations. Livestock Statistics Database, 2000.

Fernanda BM., Nilson EDS., Makoto M., Ivanor NP. and Willian GN. (2003): Evaluation of Carcass Characteristics and Meat Chemical Composition of Bos indicus and Bos indicus $\mathrm{x}$ Bos taurus Crossbred Steers Finished in Pasture Systems. In Brazilian Archives of Biology and Technology. Universidad Estadual de Maringá; Colombo, 5790; Maringa-Parana Brazil 46(4):609-616.

Gebrehiwot HW., Endale B., Yohanes H. and Kidane W. (2018): Determination of $\mathrm{pH}$ and Water Holding Capacity of Beef from Selected Butcher Shops of Mekelle, Ethiopia, Journal of Veterinary Medicine and Animal Health 10(6):159164.

Gustavson J., Cederberg C., Sonesson U., van Otterdijk R. and Meybeck A. (2011): Global Food Losses and Food Waste. Food and Agriculture Organization of the United Nations, Rome. Pp 86

Jama N., Muchenje V., Chimonyo M., Strydom PE., Dzama K. and Raats JG. (2008) Cooking Loss Components of Beef from Nguni, Bonsmara and Angus steers. African Journal of Agricultural Research. 3(6):416-420.

Kauffman RG., Eikelemboom G., Vander Wal PG. and Zaar MA. (1986): Comparison of Methods to Estimate WaterHolding Capacity in Post-Rigor Porcine Muscle. Meat Science 18:307-322.

Klaudia M. and Wojciech P. (2018): Selected Psychological Aspects of Meat Consumption-A Short Review Nutrients 10(9):1-14.

Lawrie RA. (1974). Meat Science. 4 th edition. Oxford, Pergamon Press. United Kingdom. Pp 125-129.

Lawrie, RA. and Ledward, DA. (2006): Lawrie's meat science (7th Ed.). Cambridge: Woodhead Publishing Limited. Pp. 2.

Leroy F. and Praet I. (2015): Meat Traditions: The Co-
Evolution of Humans and Meat. Appetite 90:200-211.

Maiiti AK. and Ahlawat SS. (2011): Effect of Natural Tenderizers on Physicochemical Properties of Chickens Gizzard and Goat Heart. American Journal of Food Technology, 6(1):80-86.

Nikmaram P., Said YM. and Emamjomeh Z. (2011): Effect of Cooking Methods on Chemical Composition, Quality and Cook loss of Camel Muscle (Longissimus dorsi) in Comparison with Veal. African Journal of Biotechnology, 10(51):10478-10483.

Oh, M., Kim, E., Jeon, B. and Tang, Y. (2016): Chemical Compositions, Free Amino Acid Contents and Antioxidant Activities of Hanwoo (Bos Taurus Coreanae) Beef by Cut Meat Science. 119:16-21.

Omoregie E. (2001): Utilization and Nutrient Digestibility of Mango Seeds and Palm Kernel Meal by Juveline, Labeo senegalis (Antheriniformes: Cyprinidae). Aquacultural Research (32):681-687.

Pearson AM. and Gillett TA. (1988): Processed Meat. $3^{\text {rd }}$ edition. Aspen Publishers, Inc. Gaithersburg. Pp. 210-212.

Pethick DW., Ball AJ., Banks RG. and Hocquette JF. (2011): Current and Future Issues Facing Red Meat Quality in a Competitive Market and How to Manage Continuous Improvement. Animal Production Science, 51(1):13-18.

Piatti-Farnell L. (2013). Beef: A Global History. London: Reaktion Books. Pp. 7.

Qiaofen C. and Da-Wen S. (2008): Factors Affecting the Water Holding Capacity of Red Meat Products: A Review of Recent Research Advances, Critical Reviews in Food Science and Nutrition, 48(2):137-159.

Simela L., Webb EC. and Frylinck L. (2004): Effect of Sex, Age, and Preslaughter Conditioning on $\mathrm{pH}$, Temperature, Tenderness and Colour of Indigenous South African Goats. South African Journal of Animal Science 34(5):208-211.

Soniran OG. and Okubanjo AO. (2002): Physico-Chemical and Sensory Characteristics of Pork Loin Roasted, Cooked to Three Internal Temperatures. Nigerian Journal of Animal Production 29(1):138-141.

Tornberg E. (2005): Effects of Heat on Meat ProteinsImplications on Structure and Quality of Meat Products. Meat Science 70(3):493-508.

Trout GR. (1998): Techniques for Measuring Water Binding Capacity in Muscle Foods: A Review of Methodology. Meat Science 23:235-252.

Tsegay L., Mohammed B. and Sandip B. (2015): Quality of 
Beef, Chevon and Mutton at Hawassa, Southern Ethiopia, African Journal of Food Science 9(5):301-306.

Williams PG. (2007): Nutritional Composition of Red Meat, Nutrition and Dietetics. International Livestock Research Institute. 64(2):5-30.

Yacob A. (2002): An Audit of the Livestock Marketing Status in Kenya, Ethiopia and Sudan (Volume I).Community-Based Animal Health and Participatory Epidemiology Unit (CAPE) PACE Programme, OAUIBAR. Pp. 85.

Zhang YY., Zan LS., Wang HB., Xin YP., Adoligbe CM. and Ujan JA. (2010): Effect of Sex on Meat Quality Characteristics of Qinchuan Cattle. African Journal of Biotechnology 9(28):4504-4509.

Maeda, T. (1997).A study on bond mechanism of carbon fiber sheet. FRPTCS3, 1, 279-286.

Manosr, G., Katakalos, K., Theofanous, M., Kozikopoulos, E., \& Upgrade, S. (2013). Experimental And Numerical Investigation Of Rectangular R/C Beams Retrofitted Against Shear Utilizing CFRP Strips. No. June, 12-14.
Module, I. E. (2004).An Introduction to FRP Strengthening of Concrete Structures.Prepared by ISIS Canada.A Canadian Network of Centres of Excellence.

Pellegrino, C., \& Vasic, M. (2013). Assessment of design procedures for the use of externally bonded FRP composites in shear strengthening of reinforced concrete beams. Composites Part B: Engineering, 45(1), 727-741.

Triantafillou, T. (1997). Shear strengthening of concrete members using composites. Paper presented at the Third International Symposium on Non-Metallic (FRP) Reinforcement for Concrete Structures.

Triantafillou, T. C. (1998). Shear strengthening of reinforced concrete beams using epoxy-bonded FRP composites. ACI structural journal, 95, 107-115.

Triantafillou, T. C., \& Antonopoulos, C. P. (2000). Design of concrete flexural members strengthened in shear with FRP. Journal of composites for construction, 4(4), 198-205. 